\title{
Noise, Uncertainty and Investor Psychology: A Behavioral Analysis
}

\author{
Mosbeh Hsini ${ }^{1}$ \\ ${ }^{1}$ Department of Management, Higher Institute of Accounting and Trade of Bizerte, Carthage University, Tunisia \\ Correspondence: Mosbeh Hsini, Department of Management, Higher Institute of Accounting and Trade of \\ Bizerte, Carthage University, Tunis, Tunisia. E-mail: lahsinim@gmail.com
}

Received: April 14, 2015

Accepted: May 11, 2015

Online Published: June 25, 2015

doi:10.5539/ibr.v8n7p1

URL: http://dx.doi.org/10.5539/ibr.v8n7p1

\begin{abstract}
The aim of this paper is to focus the interest on the behavioral finance contribution that helps understanding the financial market volatility. In order to put in evidence such an eventual GARCH effect between the exchange volume and the volatility of stock prices on Tunisian financial market. We borrowed the approach of Moschetto (1998) and Najand and Yung (1991) allowing the assessment of the GARCH $(1,1)$ Model. The data set consists of weekly stock prices and transaction volume. The sample period runs from January 2002 to January 2013.The results pointed to significant positive effect of volume on stock prices that highlights the investor irrational behavior when uncertainty is ruling over the market.
\end{abstract}

Keywords: Asymmetric information, noise, uncertainty, irrationality, transaction volume, stock prices, volatility, herd behavior, heuristic, investor psychology, mental anchoring

\section{Introduction}

Behavioral finance studies specifically how do individual and collective behaviors influence the securities' prices of financial assets traded on the financial markets. This new academic field was enriched by both psychologists and economists, whose pioneer works (since 1990) back to Thaler, De Bondt and Shiller. The finance domain has shift to the fact that the various operators are not fully rational in their decisions and accordingly they are subject to interpersonal influences within the market (Barberis \& Thaler, 2002). In the same vein, De Bondt and Thaler (1985), Kahneman and Riepe (1998), Shleifer (2000) Barberis et al. (1998), Bertrand and Morse (2012) highlight how some investors irrational behavior can drive stock prices away from their intrinsic values. Then, it seems somewhat hard to build models with "quasi-rational" or partially rational agents. Given the fact that the market does not work without operators where they transact, the behavioral tendencies of the latter should not be ignored. Shiller (2001), Hirshleifer (2001), Bernartzi and Thaler (2002), Chen (2003), Campbell and Taksler (2003), Clement and Tse (2004), Angel et al. (1997), Grinblatt and Kelohiarjus (2009), Gervais et al. (2011) consider that this new financial-economic trend tries to explain such human behavior. It has the characteristic of integrating notions of bounded rationality or irrationality subordinate to the limited capacities of the human mind not only for the available information treatment but also for making such a decision. This situation suggests that behavioral finance attempts to supplement standard theories of finance by introducing the behavioral aspects of financial analysis. Therefore, Hirshleifer (2001) states that behavioral finance has the potential to be a valuable supplement to the classical and neoclassical financial theory, which currently dominates the financial analysis however it seems in contrast with it. This new frontier considers indeed psychological factors as an important input for economic analysis and that is appropriate to think for other human behavior models namely psychology, sociology and anthropology, which do foster psychological profile rather than the investment one.

\section{Behavior and Reasoning Anomalies}

Behavioral finance identifies the cases where irrationalities (limited rationality) do bias the understandings and behaviors of stock actors. These biases create some pockets of market inefficiency as price anomalies (the gap between stocks prices and their intrinsic values). The behavioral analysis does pay an important interest for these anomalies hoping to take advantage for a better appreciation of risks and gain opportunities. In this frame work, four main kinds of behavioral phenomena that involve the generating source of price anomalies, regarding individual /collective cognitive errors, in addition to emotions and individual / collective hysteria.

\subsection{Individual Cognitive Errors}

The psychology literature describes several behavioral biases that may explain the observed price gaps in efficient 
markets. A first family of this biases (attention lack) which states that the human being is not always able to observe and identify the facts, does contain several forms of biases such as the mental anchor (memory) which considers that operators have in mind such reference points to the extent that when news arrives, they timidly adjust their references ( under- reaction). Later, once these informations were gradually confirmed, those agents get carried away by the current that pushes them to adjust too much (over-reaction). Besides, we mention the cognitive overload that explains the tendency to remain anchored to old facts and beliefs. Shiller $(1999,2001)$ notes that attention is a fundamental aspect of human intelligence and then the attention anomalies are behind many mistakes that people make. A final example of these attention biases refers to conservatism that represents a widespread mental trait for investors. Once they have formed such an opinion, it is too hard to change it even under the effect of new informations. Barberis and Thaler (2002) believe that people tend to keep their opinions and therefore inadequately they respond to new informations.

A second family of individual cognitive errors refers to overconfidence which postulates that individuals overestimate their informations and capacities. Everyone believes he can beat the market. The extreme case is magical thought when operators are overconfident to influence events (De Bondt \& Thaler, 1985). It is important to consider in this framework that overconfidence when coupled with the anchor can not only lead to inflate the volume of trade between investors (over trading) and therefore cause an excessive volatility, but also produce a type of curse of the winner.

The last family concerns retrospective error that affects people who have forgotten their initial assessments. Consequently, when they see the results, they tend to use them as anchor and consider that their assessments were very similar but really they do never remember at all.

\subsection{Collective Cognitive Errors/Social}

Social behavior is usually based on conventions (norms or common paradigms) that may affect the whole population or certain sections only. Among these collective biases, we point mimetic rational expectations which state that it is sometimes reasonable to follow the trend, certainly, when taking risk, that one day the tide turns harshly and the cash will be severe. Tversty and Kahneman (1979) states that behavioral analysis considers that when the majority of individuals are optimistic or pessimistic, the end of this trend is so near since it becomes difficult to convince newcomers and each defection can initiate a trend reversal. Manipulations constitute another pocket of collective biases because they are possible from one person to another, and take then a new dimension on markets; groups and crowds who are more involved than isolated individuals.

\subsection{The Various Individual and Collective Emotions}

Even emotions can be biased (prospect theory) not only when fear rules on stock market but also in normal times. Furthermore, the loss aversion is stronger than the appetite to seize gain opportunities. This may explain why the market operators do prefer to sell winner stocks of their portfolios rather than losers. In addition, the aversion to materialize the loss seems to be greater than the risk aversion. It is often only when loser stocks have fallen sharply and for a long time that fear prevails and they sell with low price. Other reasons that should be mentioned such as the commitment, the desire to minimize the subsequent regret. Also, panic can spread faster than euphoria, accompanied with rapid and massive price falls (Crash), collapse of liquidity (liquidity trap). Another example of these collective emotions concern "social psychology, emotions and collective hysteria" which considers that in such a group or a crowd, people tend to lose their own references, values and inhibitions, and therefore they may share the collective emotions, and to be dragged to act as a whole, up to the excess they would not have committed individually. There will be a kind of mimicry (more or less exalted) and a herd instinct that leads the crowd: some fashions and fads (mild form) and bubbles and crash (wild form).

\section{Sentiment and Irrationality of Operators: The Noise Traders' Model}

The research track dealing with investors' sentiment is initially introduced by Black (1986), Shiller (1984) and later developed by De Long et al. (1989, 1990, 1990b), Lee et al. (1990), Tversky and Kahneman (1982), Anderson (1996), Kahneman and Riepe (1998), Easly et al. (2002), Lynch and Musto (2003), George and Wang (2004), Sherbina (2004), Ai (2010), Hu et al. (2013), Alti and Lock (2014). This track yields a more accurate description of financial markets. Indeed, the approach via the noise traders' model is based on the questioning of the homogeneity hypothesis of operators rational expectations, and consequently allows explaining chronic instability of stock prices. This state advances new implications for asset prices pushing it to deviate from its fundamentals. This noise traders' model which describes an alternative to the efficient markets paradigm presents the effect of investor sentiment on the returns prediction and errors valuation (Brown \& Cliff, 2004). Black (1986) and Kyle (1989) suggest the term "noise traders" or "noise operators" to describe the irrational investors, who are participants acting on the basis of irrelevant information (they act according to noise, rumors, past informations ...). 
In fact, their expectations are found on incorrect beliefs that seem to be a response to changes in expectations or in feeling that are not fully justified by the information, but it is a response to such pseudo-signals (Shiller, 2001). Moreover, the feeling of noise traders is at least partly integrated in stock prices and enters within the definition of expectations formulated by rational investors. Therefore, any market participant incorporates noisy or incorrect opinions in his forecasts for the same asset rather than all relevant information. Thus, the prices already disturbed by noise will not converge to their true values. Tversky and Kahneman (1979) state that many of these mistakes are made public on the financial markets and consequently operators tend to be more confident that encourages them to take more risks and even extrapolate past time series at pursuing trends. This behavior leads to these operators to respond to information. That is noise which conducts price formation rather than information. The noise traders are divided into two groups "the positive / negative feedback traders". There are those who buy when prices rise and sell when they are falling. These are the positive feedback traders. Conversely to those, there is the negative feedback traders who buy when prices are low and sell them when getting higher. Shleifer (2000) states that recent theoretical models have shown that noise traders interact on the market with rational or sophisticated investors who made rational expectations based on fundamental information, causing consequently some changes in price which seems to be completely rational.

\subsection{The Irrationality of Financial Analysts}

Huge literatures were interested at the financial professional analysts' behavior and their impacts on the entire market. De Bondt and Thaler (1987) state that analysts systematically over-react to new information. Thus, the net predicted results are consistent with the systematic optimism of financial analysts in response to information, leading in fact to a price over-reaction that may generate waves of speculative bubbles. Other researchers have also documented that analysts 'forecast results are systematically over optimistic as Chopra et al. (1992) do indicate that Wall Street analysts tend to be optimistic about the results prospectus of the companies they supervise. Moreover, they conclude that analysts consistently overestimate the actual results during the year. They furthermore suggest that positive and predictable prejudice may be a rational property of optimal forecast results due to the reality. Despite the documented prejudices, analysts' forecasts have a significant impact on stock prices. In this context of psychological analysis, Shiller (1981) attributes the financial bias to irrationality and postulates that stock prices vary too much relatively to news about future dividends. Similarly, Hong and Stein (1999) studied the overreaction by modeling the operators' interaction who naively follow trend of prices and other operators.

\subsection{The Positive Feedback Traders}

One of the strongest trends of investors is the intention to extrapolate or pursue the trend. Therefore, they buy the stocks after they rise and sell following the fall. Thus, they follow the positive feedback strategies encouraging accordingly the deviation of prices relatively to fundamentals. De Long et al. (1989, 1990), Kyle (1989) show that the noisy "positive feedback traders' push asset prices beyond their real values, and that by buying up and selling at lower prices. Similarly, rational operators over invest in order to shut for a capital gain later. These investments undertaken simultaneously by the noise traders and also arbitrageurs will generate a rise in stock prices, and therefore an over assessment of these traded securities. Campbell and Kyle (1993) break down the performance of an action in a fundamental and other noise component and argue that the two are strongly positively correlated, meaning that prices over-react to the news. The feedback standard theory (Shiller, 1999) postulates that when stock prices rise, it creates several success stories of investors who are seduced therefore other investors who naively believe that the same success if they repeat involved too. Hence, this simplicity plays a critical role in the behavior of securities in particular and of markets in general.

\subsection{The Arbitrage Limits}

Really, the arbitrageur cannot know exactly the intrinsic value of the security or detect accurately the price, and sometimes he feels handicapped due to the difficulty of identifying the bad assessment and then he is faced with such arbitration limits. The arbitrage opportunity absence is one of the fundamental axioms of modern financial theory; since arbitration is not really an operation with certain results, but sometimes it may require capital funding. De Long et al. (1990) argue that the none predicting of noise traders beliefs generates risk in prices that diverts rational arbitrageurs. Shleifer and Summers (1990) present two types of risks that can affect arbitrage taking into account the risk aversion of investors. This is namely the fundamental risk and that of funding. Fear of losing limits the arbitration and accordingly prevents pushing prices to their fundamentals. As a result, arbitration does not eliminate the effects of noise since this later creates risk.

\section{Excessive Confidence and Operators' Irrationality}

Recently, studies and financial investigations have provided an increased interest in the analysis of behavior and effects of irrational investors who badly perceive the values distribution of financial assets. Thus, Orlean (1992, 
1994), Grandy and Martin (2001), Dumas et al. (2009), Bertrand and Morse (2012) postulate that operators are generally irrational and therefore their behaviors do expose such narrow forms of irrationality and heuristics. In this sense, operators include intertemporal influences, mimicry and contagion. These biases have often been studied by cognitive psychology (Kahneman \& Riepe, 1998; Griffin \& Tversky, 1992) who propose two different and complementary explanations which are: investors are not "Bayesian"; or they would be excessively confident in their judgments. Thus, overconfidence appears as one of behavioral biases the most treated through behavioral finance. Then, it will be necessary to highlight how individuals (rational to base) can be induced to become irrational because of psychological factors or human nature. Theoretical and empirical studies interested at the issue of over-confidence, advanced by De Long et al. (1990) and extended by Hirshleifer and Subrahmanyan (1998) Kyle and Wang (1997) and developed especially by Odean (1999), Barber and Odean (2002), De Fontrouvelle et al. (2003). Barberis et al. (1998), Diether et al. (2002), Choudhry (2007), Kogan et al. (2006), Malmendier et al. (2011) Buraschi et al. (2014) form a whole theory that helped explaining several phenomena on financial market such as the price variability, mimicry and the speculative bubbles emergence. In the literature, overconfident investors do overestimate the accuracy of their knowledge about the financial security value. Kahneman and Riepe (1998) state that investors behave overconfident only with private information signals. Thus, they could overestimate the likelihood that their personal assessment of the security value is more accurate than other competitors' assessments. This intensifies the opinion differences which does deviate the quotes away from their fundamentals. Hong and Stein (1999), Barberis and Thaler (2002) consider that excessive confidence on private information leads operators to revise their beliefs too little in response to subsequent public news. Kent and Titman (2000) define excessive confidence as if the accuracy of the error component of private information signal is larger than it really is, but operators do remain Bayesian. Furthermore, Odean (1998) emphasizes that operators' excessive confidence makes belief that the forecast of their knowledge about the security value is greater than it is now. This state implies that these operators see themselves more able to assess the securities they are interested now, but in reality, they observe a pure noise while believing they observe a useful signal; confirming more that they are overconfident about the quality of their private information. Kahneman and Riepe (1998) argue that excessive confidence in the accuracy of the operators' estimates is likely to become more extreme over time, since those who win do attribute their success to their own skill and judgment. In the same vein, according to Grimblatt and Kelohiarju (2000), overconfidence is considered as one of the strongest behavioral biases discussed in the literature. De Bondt and Thaler (1987) state that "the most robust finding in the judgment psychology is the exaggerated confidence of the operators and that every professional is exposed to this type of biased behavior of overconfidence. Gervais and Odean (1997) attempt to modelize a multi-period market describing the process by which speculators learn about their capabilities and how their learning can create overconfident speculators. As a result, their speculation success does update incorrectly their beliefs and attributes this fact to their superior abilities. They overestimate their own contributions to the past positive results by remembering more of their successes than their failures. Thus, they are led to such biased judgments. This behavioral bias leads operators to have a probability distribution that does not reflect well the fundamental value. Consequently, they make some predictions that differ from the conditional expectation of this fundamental value and underestimate the specific risk (the calculated variance is lower) and, because they mistakenly believe that they have special signals about the future price of the risky asset. De long et al. (1990) define clearly irrationality as follows: "To form an opinion and maximize their expected utility, investors give importance to market psychology besides to circulating rumors, with regards to individuals who do not act in full mind independence. For excessive confidence, investors do not only incorporate news into prices, but make their analysis and assessments based on their feelings that can easily be influenced by various behavioral biases.

\subsection{The Theory of Biased Attribution}

The biased attribution theory in psychology initially introduced by Ben (1965) and further developed by Barberis and Thaler (2002) provides that when the events occur confirming the validity of individual actions, the agent attributes it to his high own competence, while conversely when events invalidate(infirm) actions, he returns this fact to external noise. It suggests that confidence varies over time according to the fact that individual beliefs and actions are confirmed or infirmed by subsequent events. Therefore, the biased attribution constitutes a form of overconfidence and occurs once the investor confidence changes at a biased fashion as a function of their decision results. Tversky and Kahneman (1979) argue that operators overweight information which confirms their initial evaluation and vice versa underweight non-coherent signals with it (evaluation). Therefore, their estimates only contribute to produce a momentum effect.

\subsection{Overconfidence: An Explanation of Irrationality}

De Bondt and Thaler (1985-1987) stipulate that irrationality explanation is a distinction between micro and macro-economic approach of irrationality, while based on the key factor of irrationality which is overconfidence. 
For the microeconomic approach of irrationality, the main explanation of irrationality remains in overconfidence. Indeed, Kyle and Wang (1997), Kent and Titman (2000), Shleifer (2000) consider that psychological factors weigh heavily in explaining the exaggerated belief that leads some financial actors to choose the probability distributions that are not identical to those of the fundamental value. These authors also conclude that overconfidence can accentuate (worsen) and becomes dominant in the long run since fund managers ask their employees to act for the sake to eliminate other competitors. This overconfidence would come both from insufficient attention to the facts, in addition to an overestimation of their abilities. Furthermore, they state that bubbles obey the dynamics that most operators have confidence in such an asset, the more they buy, the more the price goes up and consequently more their optimism seems justified. Indeed, investors often have a skewed view of the results about their past decisions as they tend to attribute the good results of their skills rather than chance; nevertheless, errors are analyzed as noise. Thus, the experts who have a greater proportion to be over-optimistic have more overconfidence. De Bondt and Thaler (1987) report that the combination of excessive confidence and exaggerated optimism do push investors to overestimate the reliability of their knowledge and in consequence, they underestimate risks and exaggerate their ability to control events, that may lead to excessive trading volumes and accordingly to the emergence of speculative bubbles.

For the macroeconomic approach of irrationality, to further explain the concept of irrationality at the macroeconomic level, Shiller (2000) gives importance not only to the majority opinion on the decisions of such economic agents but also to regret, rumors. He shows that representativeness and the conservatism principle are the two main factors underlying the speed of market changes. These two elements are more than sufficient to create a bad market assessment by playing on investor sentiment regarding the future evolution of securities price (Barberis et al., 1998). If we add to all mentioned above, the interest of the media (to sell more numbers) and financial analysts (often dependent on investment banks, and also competing to get the information held by the firms), we obtain, according to Shiller (2000) to a quote level supported by an irrational euphoria.

\subsection{Excessive Confidence on Financial Markets}

This bias affects financial markets through trading volume, returns and stock prices. Indeed, biased opinions by way of information interpretation will have immediate effects on the markets.

The implications on the transaction volume: The transactions volume seems affected by the overconfidence of the various market participants because it appears fairly high to the extent that cannot be explained by rational markets models (standards). Thus, Odean (1998), Barber and Odean (2002) Statman and Tversky (1999), Campbell and Taksler (2003), Clement (2004), Linnainmaa (2010) show that investors operate exaggeratedly, due to excessive confidence they have more on signals with what they have great personal implications. Barber and Odean (1998) modelize this prediction by high past returns that increase the confidence of operators and transaction volume will consequently increase. Therefore, investors overestimate predicting their informations and therefore the transaction anticipated gains transaction. They could even operate when the anticipated net gains are negative, so that rational investors operate only if the anticipated gains excess transaction costs.

The implications on quotes: Barber and Odean (2002), Stein (1998) report that in a financial market, rational investors transact in the hope of increasing their returns. They add that overconfident investors lower their expected utilities by trading excessively and reduce their net returns than do rational investors. In addition, excessive confident investors are more likely to negotiate solely to improve their performances. Odean (1998) argues that investor returns are clearly affected by overconfidence biases. He expects that investors by negotiating too frequently reduce their returns due to their excessive confidence. Given these different psychological behaviors, securities that rational speculators buy over-perform those they sell. So if these speculators are informed but overestimate the accuracy of their information (a form of overconfidence), securities they buy underperform on average those they sell. Similarly if negotiators believe they have the information, but really do not, the securities they buy underperform on average significantly securities they sell. Diether et al. (2002), Lynch and Musto (2003) follow the same line of research a similar approach, showing that overly confident investors are growing more strongly their own assessments of the assets than other operators, and as a result, the so-called overconfidence leads to heterogeneous beliefs and differences of opinion. Barberis et al. (1998), Haigh and List (2004), Baker and Wurgler (2006), Titman and Daniel (2008), Easly and O'Hara (2010) argue that every overly confident investor believes that the beliefs of his competitors fluctuate randomly around his own beliefs, thus agree to a linear diffusion process of mean reversion.

\section{Empirical Investigation of Behavioral Bias Market}

We will try to test possible effects of psychology or followership on the Tunis Stock market where we ask is it possible to capture a GARCH effect on the returns of the securities with or without transaction volume taken as an 
explanatory variable in the equation of the conditional variance? However, before starting the empirical analysis it is essential to clarify the theoretical relationship between the support variables of this investigation as the stock price and trading volume. Hirshleifer (2001) Sherbina (2004), Kahneman and Tversky (2000), Linnainmaa (2010) state that when the uncertainty rules over the market and operators feel themselves ravaged by a wave of psychology crowd, these individuals prefer therefore do not deviate from the average opinion of the market in order not to incur too much risk. This state of mind does push them to align with the majority opinion over the market, even at the expense of their privileged information. Thus, such a phenomenon of lead-lag on the market is forged. The followers (lag), the main actors of this new motion, are mainly composed of uninformed operators. They constitute such a group of attentive operators to each signal sent to the market by the informed presumed (lead). These same people (lag) do not take positions based on their beliefs or their own expectations, since without a lag, their activity is worth nothing (zero) and their investment decisions are subordinate to the market reading they do. In other words, the size and direction of their transactions seem to be influenced by the equivalent parameters of the market interveners at time t. It is very important to consider that for a same price level, there will be swelling of the transactions' volume. Furthermore, the additional volume that can be observed proves the only followers' reflection since by transmitting orders similarly to the newly interveners on the market, they hope making such a profit through this behavior. Thus, the volumes will increase systematically and generate consequently an increase at stock prices. Therefore, variables designed to measure and quantify this type of behavior as the transaction volume and the price of each security remain among the best examples of this kind of variables. In this context, the tests on the persistence of ARCH effects in the presence or absence of the variable volume are considered as the most appropriate to modelize the investors' behavior on stock market. In fact, these GARCH models are viewed as the best suited for this type of distribution to modelize the relationship between the trading volume and price volatility. The GARCH (1.1) appears as the most effective of the family since it has a strong predictive ability of detecting a possible correlation between volume and price variability.

\subsection{The Model Presentation}

Najand and Yung (1991), Moschetto (1998), based on a GARCH $(1,1)$ model for the sake to examine the relationship between volume and price volatility of a futures contract on the CBOT and the notional respectively, do consider two distinct specifications:

The first one is intended for the conditional mean:

$$
z_{t}=y_{t}+\delta+\varepsilon_{t}
$$

The second has a destiny for the conditional variance:

$$
\begin{gathered}
h_{t}=w+\alpha \varepsilon_{t-1}^{2}+\beta h_{t} \\
\varepsilon_{t} / \Phi_{t-1} \rightarrow N\left(O, h_{t}\right)
\end{gathered}
$$

The terms of the conditional variance equation are:

w: The conditional mean;

$\varepsilon_{\mathrm{t}-1}^{2}$ : The news of the volatility of the previous period determined from the relation (1) cited above;

$\mathrm{h}_{\mathrm{t}-1:}$ : The expected variance of the previous period.

\subsection{Assumptions}

To modelize this relationship price-volume, four hypotheses are needed:

$\mathbf{H}_{\mathbf{1}}$ : The existence of a lead-lag relationship between operators.

$\mathbf{H}_{2}$ : The majority opinion causes swelling of the transaction volume which will generate an increase in prices of securities.

$\mathbf{H}_{3}$ : The time lag in the decision making of some agents amplifies the psychological behavior on the market.

$\mathbf{H}_{\mathbf{4}}$ : The volume influences the securities price volatility.

\subsection{Data and Empirical Procedures}

\subsubsection{Data}

Our empirical investigation examines such as the positive correlation between volume and price volatility of shares traded on the Tunisian stock market is based on a database composed of two time series of prices and trading volume, over a period stretching from January 2002 to January 2013, for daily data. 


\subsubsection{Methodology}

In order to highlight possible GARCH effect between trading volume and volatility of stock prices on the place of Tunis, we followed the approach Moschetto (1998) to estimate the GARCH (1.1) without and with transaction volume (lag 0 or 1 ), and jointly for series $\mathrm{C}_{\mathrm{t}}$ and $\left|C_{t}\right|$.

\subsubsection{Preliminary Results}

\subsubsection{Descriptive Statistics}

* The tests of skewness and kurtosis: The normal distribution is characterized by the symmetry with respect to the mean, and the low probability of extreme points. We recall, in this context, that if the distribution is normal and the number of observations is greater than thirty (30) the coefficient of skewness (S) is zero and the kurtosis coefficient $(\mathrm{K})$ is equal to three.

* The Jarque and Bera test (JB): This test that synthesizes the coefficients of skewness and kurtosis. The JB which is based on the concept of skewness (asymmetry) and kurtosis (flattening) does enable to verify the normality of the statistical distribution. Thus, once the JB coefficient follows a chi-square with two degrees of freedom and it is more than chi-square (5.99), there is a rejection of the null hypothesis of normality.

\subsubsection{Stationarity Tests}

* Tests Dickey and Fuller: Dickey and Fuller statistics are intended to test the null hypothesis of non-stationary processes against the alternative hypothesis of the stationary one. Their interest is to inform about the need to differentiate the studied series. Dickey and Fuller have derived the least squares estimators, besides the Student statistics of the estimated coefficients to facilitate the test application.

* Philips Perron Test: This test is an extension of Dickey and Fuller tests. The models on which the Philips Perron test is applied are identical to those used by Dickey and Fuller. Furthermore, the asymptotic distributions of Philips Perron and Dickey and Fuller are identical, and it is sufficient only to refer to the critical values Dickey and Fuller tables.

\subsubsection{Comments}

The study of the statistical properties reveals some findings as:

* The application of ADF tests on the series of both the average prices and stock return of the securities revealed the presence of a unit root in all series of average prices at level. Similarly, the series of stock returns are all stationary at level.

* The normality null hypothesis is rejected for all stock return series and since the value of the Jarque -Bera statistic exceeds amply the tabulated value of the chi square, at two degree of freedom. Furthermore, we observe a skewness coefficient different to zero suggesting the none flattening of the distribution density function (too upward). This observation is confirmed by the rejection of the normality assumption (the Jarque-Bera statistic $(\mathrm{JB})>\operatorname{chi} 2)$. For stationary coefficients, the result of statistical test shows that the two series studied $\left[\mathrm{Ct}^{*}{ }_{\mathrm{t}}\right.$ and $\left.\mid C_{t}{ }^{*}\right]$ are stationary at level, since the ADF statistic (respectively are - 30.34 and -39.82) is less than the critical value and at the $1 \%, 5 \%$ and $10 \%$ level. The results of the GARCH estimation (1. 1) are presented as follows:

Table 1. Parameter estimation GARCH $(1,1)$ average price regardless of volume (Biat)

\begin{tabular}{lccc}
\hline & Coefficient & Statistic z & Significance level \\
\hline$\mu$ & $6,37 \mathrm{E}-05$ & 0,330943 & 0.7407 \\
$\alpha_{0}$ & $1,87 \mathrm{E}-05$ & 16,23080 & 0.0000 \\
$\alpha_{1}$ & 0,192187 & 14,24392 & 0.0000 \\
$\mathrm{~B}$ & 0,690026 & 40,24951 & 0.0000 \\
$\alpha_{1}+\beta$ & 0,881054 & - & - \\
\hline
\end{tabular}


The coefficients $\alpha_{0}, \alpha_{1}, \beta$ are all significant at the $1 \%$ level synonym of the presence of a GARCH effect. Furthermore $\left(\alpha_{1}+\beta\right)$ is slightly less than unity which confirms that the conditional variance is persistent hence and then the existence of a quasi-IGARCH $(1,1)$.

Table 2. Estimating GARCH $(1,1)$ average price with gross volume $\delta$ (delay zero)

\begin{tabular}{llcc}
\hline & Coefficient & Statistic z & Significance level \\
\hline$\mu$ & $1,12 \mathrm{E}-05$ & 0,057935 & 0.7407 \\
$\alpha_{0}$ & $1,87 \mathrm{E}-05$ & 16,19641 & 0.0000 \\
$\alpha_{1}$ & 0,190928 & 14,10385 & 0.0000 \\
$\mathrm{~B}$ & 0,690026 & 41,58730 & 0.0000 \\
$\alpha_{1}+\beta$ & 0,881054 & - & - \\
$\delta$ & $3,72 \mathrm{E}-06$ & 8,433619 & 0,0000 \\
\hline
\end{tabular}

The coefficients $\alpha_{0}, \alpha_{1}, \beta$ and $\delta$ are all significant at the $1 \%$ level. Similarly, there is a persistence of the conditional variance at the presence of the volume variable. The sum $\left(\alpha_{1}+\beta\right)$ is close to unity, which proves the persistence of past volatility in the explanation of the current volatility of the price.

Table 3. Estimation of the GARCH regression (1.1) parameters: average price volume with lag (1)

\begin{tabular}{cccc}
\hline & Coefficient & Statistic z & Significance level \\
\hline$\mu$ & 0,000215 & 0,01896 & 0.1922 \\
$\alpha_{0}$ & $4,99 \mathrm{E}-05$ & 11,74720 & 0.0000 \\
$\alpha_{1}$ & 0,153882 & 10,79991 & 0.0000 \\
$\mathrm{~B}$ & 0,564449 & 18,04883 & 0.0000 \\
$\alpha_{1}+\beta$ & 0,718331 & - & - \\
$\delta$ & $-1,5 \mathrm{E}-05$ & $-44,53954$ & 0,0000 \\
\hline
\end{tabular}

The third regression results are very close to those of the previous one, except that in this case the volume lag (1) is taken into account in explaining price volatility. Thereafter, we retake the case of GARCH estimates (1.1) with "absolute value" of the average price $\left|C_{t}\right|$ with and without trading volume, and in order to refine more our analysis. The estimates of the three types of GARCH, EGARCH and TGARCH models allowed us to adopt the EGARCH representation to modelize the volatility of the absolute average return with introduction of variable volume with a lag of (1) delay, and since the ratios of maximum likelihood and the criterion of Schwartz and Ackaike are the highest compared to the other two models (GARCH and TGARCH). This rule of choice has been adopted in estimating all other cases. In sum, our results seem to confirm the theoretical models admitting the existence of a positive effect of volume on the persistent volatility in GARCH effect combined with a positive correlation between the volume and volatility of stock prices on the Tunis Stock market. Our results support the work of Najand and Yung (1991) and Moschetto (1998).

\section{Conclusion}

The interest of this paper is focus around the contribution of behavioral finance to understanding the volatility of financial markets. The traditional fundamental approach to finance is based on the classical assumptions of rationality where market interveners are assumed to be able to react and to revise their expectations according to Bayes' theorem when new informations arrive to market. In contrast, behavioral finance cuts with the traditional 
thought and considers that the analysis is not yet based on the fundamental calculations but rather on the behavior and sentiment operators on the market. Owing to most of the operators are so far to behave according to the fundamental model, an abundant literature on cognitive psychology has shown that they are not always able to properly deal with the new information and they do not behave fully rational. De Bondt and Thaler (1985), Barberis et al. (1998); Daniel et al. (1998), Tversky and Kahneman (2000), Benartzy and Thaler (2002), Malmendier et al. (2011), Bernard and Morse (2012) specify that the contributions of behavioral finance to understanding the puzzle of volatility are of two types: taking into account the arbitrage limits besides to the psychology of individuals. Therefore, this new vision of finance offers two opposing models related to investor behavior. Namely, it is the over-reaction and under-reaction. Accordingly, such aberrant returns are regarded attributed to a limited rationality or even to operators' irrationality. The empirical validation was dedicated to estimating the parameters of GARCH regressions (1.1) average price with and without introduction of the variable transaction volume. Our results indicate a positive effect of volume on the volatility of stock prices, on one hand, and a persistence of GARCH effect even with the inclusion of the volume within the equation of the conditional variance, on the other side. Thus, our results corroborate the theoretical and even empirical investigations and especially Najand and Yung (1991) and Moschetto (1998) about the psychological phenomenon or the followership which provides that the volume increase will be combined with a rise in stock prices.

\section{References}

Alti, A. T., \& Lock, P. C. (2014). Biased beliefs, asset prices, and investment: A structural approach. Journal of Finance, 69(1), 325-361. http://dx.doi.org/10.1111/jofi.12089

Anderson, T. (1996). Return volatility and trading volume. Journal of Finance, 51, 169-204. http://dx.doi.org/10.1111/j.1540-6261.1996.tb05206.x

Angel, J. J., Gastineau, D. L., \& Weber, C. J. (1997). Reducing the market impact of large stock trades. Journal of Portfolio Management, 24(1), 69-76. http://dx.doi.org/10.3905/jpm.1997.409629

Asparouhova, E., Bessem, B. H., \& Kalcheva, I. (2013). Noisy prices and inference regarding returns. Journal of Finance, 68, 665-714. http://dx.doi.org/10.1111/jofi.12010

Baker, M., \& Stein, J. (2004). Market liquidity as a sentiment indicator. Journal of Financial Markets, 4(2), 277-282. http://dx.doi.org/10.1016/j.finmar.2003.11.005

Baker, M., \& Wurgler, J. (2000). The equity share in new issues and aggregate stock returns. Journal of Finance, 55(5), 2219-2257. http://dx.doi.org/10.1111/0022-1082.00285

Baker, M., \& Wurgler, J. (2004). A catering theory of dividends. Journal of Finance, 59(3), 1125-1165. http://dx.doi.org/10.1111/j.1540-6261.2004.00658.x

Baker, M., \& Wurgler, J. (2006). Investor sentiment and the cross-section of stock returns. Journal of Finance, 61(4), 1645-1679. http://dx.doi.org/10.1111/j.1540-6261.2006.00885.x

Barber, N., \& Odean, F. (2002). Trading is hazardous to your wealth: The common stock performance of individual investor. Journal of Finance, 57(2), 773-806. http://dx.doi.org/ 10.1111/0022-1082.00226

Barberis, N., \& Thaler, R. (2002). A survey of behavioural finance. http://dx.doi.org/10.2139/ssrn.327880

Barberis, N., Shleifer, A., \& Vishny, R. (1998). A model of investor sentiment. Journal of Financial Economics, 49, 307-348. http://dx.doi.org/10.1016/S0304-405X(98)00027-0

Benartzy, S., \& Thaler, R. (2002). How much is investor autonomy worth? Journal of Finance, 57(4), 1593-1616. http://dx.doi.org/10.1111/1540-6261.00472

Bertrand, M., \& Morse, A. (2012). Information disclosure, cognitive biases, and payday borrowing. Journal of Finance, 66(6), 1865-1891. http://dx.doi.org/10.1111/j.1540-6261.2011.01698.x

Black, F. (1986). Noise. Journal of Finance, 41(3), 529-543. http://dx.doi.org/10.1111/j.1540-6261.1986.tb04513.x

Bloomfield, R., O'Hara, M., \& Saar, G. (2009). How noise trading affects markets: An experimental Analysis? Review of Financial Studies, 22(6), 2275-2302. http://dx.doi.org/10.1093/rfs/hhn102

Buraschi, A., Trojani, F., \& Vedolin, A. (2014). When uncertainty blows in the Orchard: Comovement and equilibrium volatility risk premia. Journal of Finance, 19, 101-137. http://dx.doi.org/10.1111/jofi.12095

Campbell, J., \& Kyle, A. (1993). Smart money, noise trading, and stock price behavior. Quarterly Journal of 
Economics, 108, 905-939. http://dx.doi.org/10.2307/2118454

Campbell, J., \& Taksler, G. (2003). Equity volatility and corporate yields. Journal of Finance, 58, 2321-2350. http://dx.doi.org/10.1046/j.1540-6261.2003.00607.x

Chopra, N., Lakonishok, J., \& Ritter, J. (1992). Measuring abnormal performance: Do stocks over react? Journal of Financial Economics, 131, 235-268. http://dx.doi.org/10.1016/0304-405X(92)90005-I

Choudhry, M. (2007). Bank Asset and Liability Management: Strategy, trading, analysis. Printed by Saik Wah Press Pte Ltd.

Clement, M. (2004). Financial analyst characteristics and herding behavior in forecasting. Journal of Finance, 60(1), 307-341. http://dx.doi.org/10.1111/j.1540-6261.2005.00731.x

Copeland, T. E., \& Galai, D. (1983). Information effects of the bid-ask spread. Journal of Finance, 38(5), 1457-1469. http://dx.doi.org/10.1111/j.1540-6261.1983.tb03834.x

Corowin, S. A. (1999). Differences in trading behavior across NYSE specialist firms. Journal of Finance, 54(2), 721-746. http://dx.doi.org/10.1111/0022-1082.00123

Daniel, K., \& Titman, S. (2000). Market efficiency in an irrational world. NBER Working Paper No. w7489. Retrieved from http://ssrn.com/abstract=207708

Daniel, K., Hirshleifer, D., \& Subrahmanyan, A. (1998). Investor psychology and security market under-Overreaction. Journal of Finance, 53, 1839-1886. http://dx.doi.org/10.1111/0022-1082.00077

De Bondt, W. F. M., \& Thaler, R. (1985). Does the stock market over react. Journal of Finance, 40(3), 793-808. http://dx.doi.org/10.1111/j.1540-6261.1985.tb05004.x

De Bondt, W. F. M., \& Thaler, R. (1987). Further evidence on investor overreaction and stock market seasonality. Journal of Finance, 42, 557-581. http://dx.doi.org/10.1111/j.1540-6261.1987.tb04569.x

De Long, N., Shleifer, B., Summers, F., \& Waldman, C. (1989). The size and incidence of the losses from noise trading. Journal of Finance, 44, 681-696. http://dx.doi.org/10.1111/j.1540-6261.1989.tb04385.x

De Long, N., Shleifer, B., Summers, F., \& Waldman, C. (1990a). Noise trader risk in financial markets. Journal of Political Economy, 98, 703-738. http://dx.doi.org/10.1086/261703

De Long, N., Shleifer, B., Summers, F., \& Waldman, C. (1990b). Positive feedback investment strategies and destabilizing rational speculation. Journal of Finance, 45, 375-395. http://dx.doi.org/10.2307/2328662

Diether, K., Malloy, C., \& Scherbina, A. (2002). Differences of opinions and the cross-section of stock returns. Journal of Finance, 57, 2113-2142. http://dx.doi.org/10.1111/0022-1082.00490

Dumas, B., Kurshev, A., \& Uppal, R. (2009). Equilibrium portfolio strategies in the present of sentiment risk and excess volatility. Journal of Finance, 64, 579-630. http://dx.doi.org/10.1111/j.1540-6261.2009.01444.x

Easley, D., \& O'Hara, M. (2010). Microstructure and ambiguity. Journal of Finance, 65(5), 1817-1846. http://dx.doi.org/10.1111/j.1540-6261.2010.01595.x

Easley, D., Hvidkjar, S., \& O'Hara, M. (2002). Is information risk a determinant of asset returns? Journal of Finance, 57, 2185-2222. http://dx.doi.org/10.1111/1540-6261.00493

Fama, E. (1965). The behavior of stock market prices. Journal of Business, 38, 34-106. http://dx.doi.org/10.1086/294743

George, T., \& Huang, C. (2004). Week hieg and momentum investing. Journal of Finance, 59(5), 211-229. http://dx.doi.org/10.1111/j.1540-6261.2004.00695.x

Gervais, S., \& Odean, T. (1997). Learning to be overconfident. Review of Financial Studies, 14, 1-27. http://dx.doi.org/10.2139/ssrn.36313

Gervais, S., Heaton, J. B., \& Odean, T. (2011). Overconfidence, compensation contrasts, and capital budgeting. Journal of Finance, 66, 1735-1576. http://dx.doi.org/10.1111/j.1540-6261.2011.01686.x

Grandy, B. D., \& Martin, J. S. (2001). On the survival of overconfidence traders in a competitive market. Journal of Financial Market, 4, 73-84. http://dx.doi.org/10.1016/S1386-4181(00)00014-8

Griffin, D., \& Tversky, A. (1992). The weighing of evidence and determinant of confidence. Journal of Finance, 4, 411-432. http://dx.doi.org/10.1017/CBO9780511808098.015

Grinblatt, M., \& Keloharjus, M. (2009). Sensation seeking overconfidence and trading activity. Journal of Finance, 
64, 549-578. http://dx.doi.org/10.1111/j.1540-6261.2009.01443.x

Hahneman, D., \& Riepe, A. (1998). Aspects of investor psychology. Journal of Portfolio Management, 24, 52-65. http://dx.doi.org/10.3905/jpm.1998.409643

Haigh, M., \& List, J. (2004). Do professional traders exhibit myopic loss aversion? An experimental analysis. Journal of Finance, 60(1), 412-427. http://dx.doi.org/10.1111/j.1540-6261.2005.00737.x

Hirshleifer, D. (2001). Investor psychology and asset pricing. Journal of Finance, 56, 1533-1597. http://dx.doi.org/10.1111/0022-1082.00379

Hirshleifer, D., \& Subrahmanyam, A. (1998). Security analysis and trading pattern when investor receives information before other. Journal of Finance, 49, 1665-1668. http://dx.doi.org/10.1111/j.1540-6261.1994.tb04777.x

Hong, H., \& Stein, J. C. (1999). A unified theory of under reaction momentum trading and overreaction in asset markets. Journal of Finance, 54, 21-43. http://dx.doi.org/10.1111/0022-1082.00184

Hong, H., Lim, T., \& Stein, J. C. (2000). Bad news travels slowly: Size, analyst coverage, and the profitability of momentum strategies. Journal of Finance, 1, 265-294. http://dx.doi.org/10.1111/0022-1082.00206

Hu, G. X., Pan, J., \& Wang, J. (2013). Noise as information for illiquidity. Journal of Finance, 68, 2341-2382. http://dx.doi.org/10.1111/jofi.12083

Kahneman, D., \& Tversky, A. (2000). Choice, values and frames (1st ed.). Cambridge University Press.

Karpoff, J. M. (1986). A theory of trading volume. Journal of Financial Economics and Quantitative Analysis, 22, 108-126. http://dx.doi.org/10.2307/2328164

Kogan, L., Ross, S. A., Wang, J., \& Westerfiled, M. M. (2006). The price impact and survival of irrational traders. Journal of Finance, 61, 195-230. http://dx.doi.org/10.1111/j.1540-6261.2006.00834.x

Kumar, A., \& Lec, C. M. (2006). Retail investor sentiment and return comovements. Journal of Finance, 61, 2451-2486. http://dx.doi.org/10.1111/j.1540-6261.2006.01063.x

Kyle, A. (1989). Informed speculation with imperfect competition. Review of Economic Studies, 5, 317-355. http://dx.doi.org/10.2307/2297551

Kyle, A., \& Wang, F. (1997). Speculation duopoly with argument to disagree. Journal of Finance, 525(5), 2073-2090. http://dx.doi.org/10.1111/j.1540-6261.1997.tb02751.x

Lee, C. M., Shleifer, A., \& Thaler, R. (1991). Investor sentiment and the closed end fund puzzle. Journal of Finance, 46, 75-110. http://dx.doi.org/10.1111/j.1540-6261.1991.tb03746.x

Lee, Y. T., Lin, J. C., \& Liu, Y. J. (1999). Trading patterns of big versus small players in an emerging market. Journal of Banking and Finance, 23(5), 701-725. http://dx.doi.org/10.1016/S0378-4266(98)00116-2

Leland. H. (1992). Insider trading. Journal of Political Economic, 100(4), 859-887. http://dx.doi.org/10.1086/261843

Linnainmaa, J. T. (2010). Do limit orders alter inferences about investor performance and behavior? Journal of Finance, 65, 1473-1506. http://dx.doi.org/10.1111/j.1540-6261.2010.01576.x

Lowenstein, M., \& Willard, G. A. (2006). The limits of investor behavior. Journal of Finance, 61, 231-258. http://dx.doi.org/10.1111/j.1540-6261.2006.00835.x

Lynch, A., \& Musto, D. (2003). How investors interpret past returns. Journal of Finance, 58, 2033-2059. http://dx.doi.org/10.1111/1540-6261.00596

Malmendier, U., Tate, G., \& Yan, J. (2011). Over confidence and early-life experiences: The effect of managerial traits on corporate financial policies. Journal of Finance, 66, 1687-1733. http://dx.doi.org/10.1111/0022-1082.00072

Moschetto, B. (1998). Mimétisme et marchés financiers. Edition Economica.

Najand, M., \& Yung, B. (1991). Mimétisme et Marchés Financiers. Edition Economica (1998).

Odean, T. (1998). Are investors reluctant to realize their losses? Journal of Finance, 53(5), 1775-1798. http://dx.doi.org/10.1111/0022-1082.00072

Odean, T. (1999). Do investors trade too much? American Economic Review, 89, 1279-1298. http://dx.doi.org/10.1257/aer.89.5.1279 
Orlean, A. (1990). Le rôle des influences interpersonnelles dans la détermination des cours boursiers. Revue Economique, 5, 839-868. http://dx.doi.org/10.2307/3501792

Orlean, A. (1992). Contagion des opinions et fonctionnement des marchés financiers. Revue Economique, 4, 685-697. http://dx.doi.org/10.2307/3501837

Orlean, A. (1994). Bayesian interaction and collective dynamics of opinion. Journal of Economics Behavior and Organization, 28, 257-274. http://dx.doi.org/10.1016/0167-2681(95)00035-6

Sapp, T., \& Tiwari, A. (2004). Does stock return momentum explain the smart money effect? Journal of Finance, 28(2), 257-274. http://dx.doi.org/10.1111/j.1540-6261.2004.00710.x

Scherbina, A. (2004). Analyst disagreement, forecast bias and stock returns. Harvard Business School, working paper series N05. 2003. http://dx.doi.org/10.1086/261843

Scott, M., \& Statman, S. (1998). How useful the sentiment index? Financial Analyst Journal, 2, 54-65.

Shiller, R. (2000). Measuring bubble expectation and investor confidence. Journal of Psychology and Financial Markets, 1(1). http://dx.doi.org/10.1207/S15327760JPFM0101_05

Shiller, R. (2001). Bubbles, human judgment and expert opinion. Financial Analysts Journal, 58(3), 18-26. http://dx.doi.org/10.2469/faj.v58.n3.2535

Shiller, R. J. (1981). Do stock prices move too much be justified by subsequent changes in dividends? American Economic Review, 71, 421-436. http://dx.doi.org/10.1086/261843

Shiller, R. J. (1984). Stock prices and social dynamics. Economic Activity, 2, 457-498. http://dx.doi.org/10.2307/2534436

Shiller, R. J. (1999). Measuring bubble expectations and investor confidence. Working paper 7008. http://dx.doi.org/10.1086/261843

Shiller, R. J. (2000a). Market volatility. MIT Press.

Shiller, R. J. (2000b). Irrational exuberance. Princeton UP, Oxford.

Shleifer, A. (2000). Inefficient markets: An introduction to behavioral finance. Oxford University press. http://dx.doi.org/10.1257/jep.4.2.19

Shleifer, A., \& Summers, L. (1990). The noise trader approach to finance. Journal of Economic Perspectives, 4 , 19-33. http://dx.doi.org/10.1257/jep.4.2.19

Shleifer, A., \& Vishny, R. (1997). The limits of arbitrage. Journal of Finance, 52, 35-55. http://dx.doi.org/10.1111/j.1540-6261.1997.tb03807.x

Smirlock, M., \& Starks, L. (1986). An empirical analysis of the stock price volume relationship. Journal of Banking and Finance, 12, 31-41. http://dx.doi.org/10.1016/0378-4266(88)90048-9

Statman, A., \& Tverkey, H. (1999). Overconfidence disposition and trading volume. Working paper, SSRN.

Stein, M. (1998). Over reaction in the option market. Journal of Finance, 44, 1011-1023. http://dx.doi.org/10.1111/j.1540-6261.1989.tb02635.x

Tversky, A., \& Kahneman, D. (1974). Judgment under uncertainty: Heuristics and biases. Science, 185, 1124-1131. http://dx.doi.org/10.1126/science.185.4157.1124

Tversky, A., \& Kahneman, D. (1979). Prospect theory: An analysis of decision under risk. Economica, 47(2), 263-292. http://dx.doi.org/10.2307/1914185

Tversky, A., \& Kahneman, D. (1982). Judgment under uncertainty: Heuristics and biases. Cambridge University Press.

Zhang, X. F. (2006). Information Uncertainty and Stock Returns. Journal of Finance, 61, 105-139. http://dx.doi.org/10.1111/j.1540-6261.2006.00831.x

Ziegler, A. (2001). Optimal portfolio choice under heterogeneous beliefs. European Finance Review, 4, 45-59. http://dx.doi.org/10.1111/j.1540-6261.2006.00831.x 


\section{Appendix}

\section{Appendix 1. Rc Biat sans volume}

Dependent Variable: RCBIAT

Method: ML - ARCH (Marquardt) - Normal distribution

Date: 12/27/13 Time: 07:10

Sample (adjusted): 22561

Included observations: 2560 after ajustements

Convergence achieved after 13 iterations

Variance backcast: ON

$\mathrm{GARCH}=\mathrm{C}(1)+\mathrm{C}(2) * \operatorname{RESID}(-1)^{\wedge} 2+\mathrm{C}(3)^{*} \operatorname{GARCH}(-1)$

\begin{tabular}{|c|c|c|c|c|}
\hline & Coefficient & Std. Error & z-Statistic & Prob. \\
\hline & \multicolumn{4}{|c|}{ Variance Equation } \\
\hline $\mathrm{C}$ & $1.87 \mathrm{E}-05$ & $1.15 \mathrm{E}-06$ & 16.23080 & 0.0000 \\
\hline $\operatorname{RESID}(-1)^{\wedge} 2$ & 0.192187 & 0.013493 & 14.24392 & 0.0000 \\
\hline GARCH (-1) & 0.690061 & 0.017145 & 40.24951 & 0.0000 \\
\hline R-squared & -0.001385 & \multicolumn{2}{|c|}{ Mean dependent var } & 0.000455 \\
\hline Adjusted R-squared & -0.002168 & \multicolumn{2}{|c|}{ S.D. dependent var } & 0.012230 \\
\hline S.E. of regression & 0.012243 & \multicolumn{2}{|c|}{ Akaike info criterion } & -6.180258 \\
\hline Sum squared resid & 0.383272 & \multicolumn{2}{|c|}{ Schwarz criterion } & -6.173405 \\
\hline Log likelihood & 7913.730 & \multicolumn{2}{|c|}{ Durbin-Watson stat } & 1.903643 \\
\hline
\end{tabular}

\section{Appendix 2. RcBiatavecvolumebrut}

Dependent Variable: RCBIAT

Method: ML - ARCH (Marquardt) - Normal distribution

Date: 12/27/13 Time: 07:22

Sample (adjusted): 22561

Included observations: 2560 after adjustments

Convergence achieved after 27 iterations

Variance backcast: ON

$\mathrm{GARCH}=\mathrm{C}(1)+\mathrm{C}(2) * \mathrm{RESID}(-1)^{\wedge} 2+\mathrm{C}(3)^{*} \mathrm{GARCH}(-1)+\mathrm{C}(4) * \mathrm{VBBIAT}$

\begin{tabular}{lllll}
\hline & Coefficient & Std. Error & z-Statistic & Prob. \\
\hline Variance Equation & & \\
\hline RESID (-1)^2 & $1.53 \mathrm{E}-05$ & $1.07 \mathrm{E}-06$ & 14.32338 & 0.0000 \\
GARCH (-1) & 0.176284 & 0.014815 & 11.89894 & 0.0000 \\
VBBIAT & 0.655147 & 0.016655 & 39.33667 & 0.0000 \\
\hline R-squared & $4.80 \mathrm{E}-11$ & $3.09 \mathrm{E}-12$ & 15.53793 & 0.0000 \\
Adjusted R-squared & -0.001385 & Mean dependent var & 0.000455 \\
S.E. of regression & -0.002560 & S.D. dependent var & 0.012230 \\
Sum squared resid & 0.012245 & Akaike info criterion & -6.197480 \\
Log likelihood & 0.383272 & Schwarz criterion & -6.188343 \\
\hline
\end{tabular}




\section{Appendix 3. Rc Biat avec volume brut retardé}

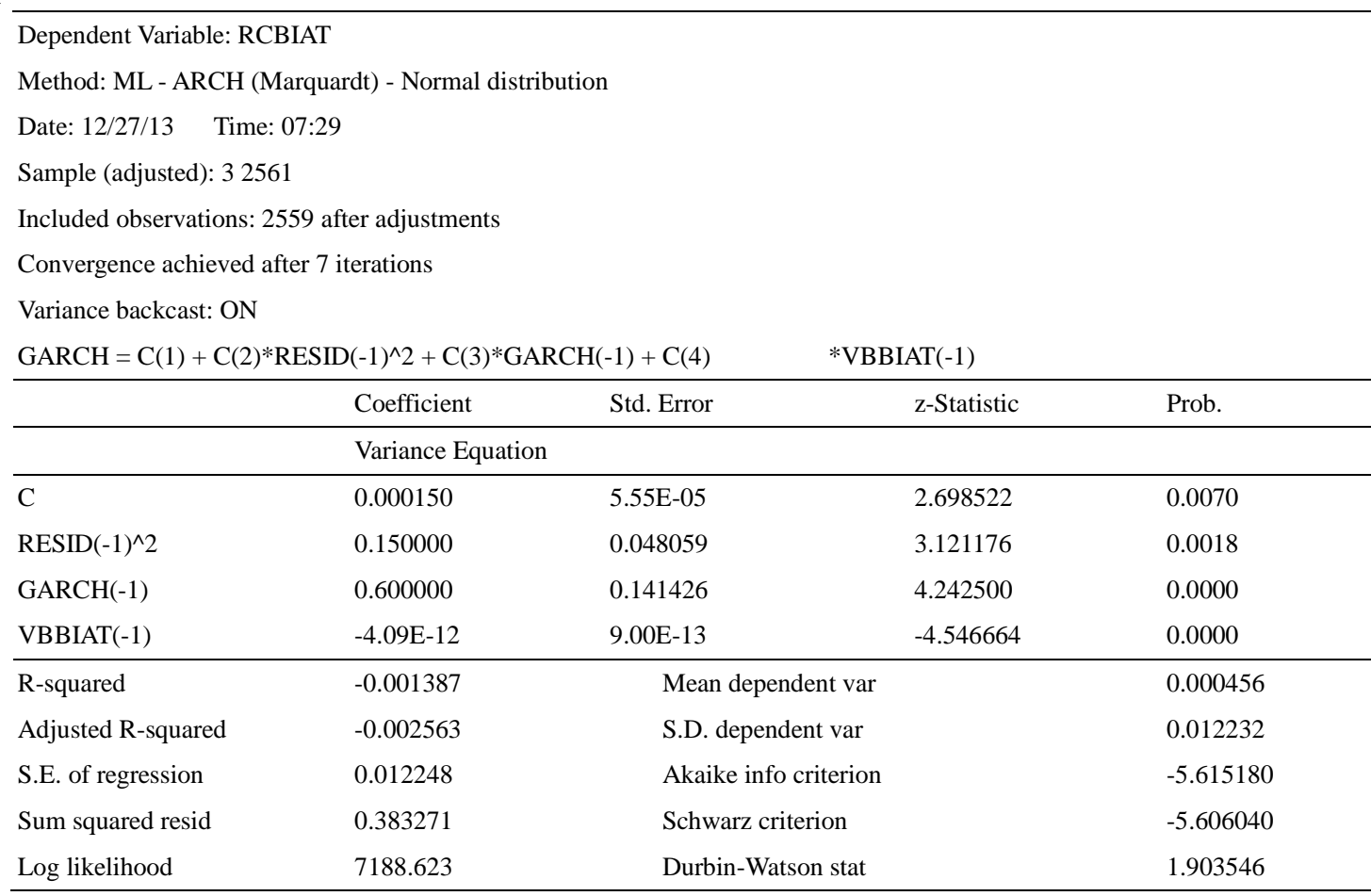

\section{Appendix 4. Augmented Dickey-fuller Unit Root test on Rcbiat}

Null Hypothesis: RCBIAT has a unit root

Exogenous: Constant

Lag Length: 0 (Automatic based on SIC, MAXLAG=26)

\begin{tabular}{lccc}
\hline & \multicolumn{1}{c}{ t-Statistic } & \multicolumn{1}{c}{ Prob.* } \\
\hline Augmented Dickey-Fuller test statistic & -48.24873 & 0.0001 \\
Test critical values: & $1 \%$ level & -3.432712 & \\
& $5 \%$ level & -2.862469 & \\
$10 \%$ level & -2.567310 & \\
\hline
\end{tabular}

Note. *MacKinnon (1996) one-sided p-values.

\section{Appendix 5. Augmented Dickey-Fuller Test Equation}

\begin{tabular}{|c|c|c|c|c|}
\hline \multicolumn{5}{|c|}{ Dependent Variable: D(RCBIAT) } \\
\hline \multicolumn{5}{|c|}{ Method: Least Squares } \\
\hline \multirow{2}{*}{\multicolumn{5}{|c|}{$\begin{array}{l}\text { Date: } 12 / 27 / 13 \quad \text { Time: } 21: 34 \\
\text { Sample (adjusted): } 32561\end{array}$}} \\
\hline & & & & \\
\hline \multicolumn{5}{|c|}{ Included observations: 2559 after adjustments } \\
\hline Variable & Coefficient & Std. Error & t-Statistic & Prob. \\
\hline RCBIAT(-1) & -0.953486 & 0.019762 & -48.24873 & 0.0000 \\
\hline $\mathrm{C}$ & 0.000434 & 0.000242 & 1.795399 & 0.0727 \\
\hline R-squared & 0.476554 & \multicolumn{2}{|c|}{ Mean dependent var } & $-6.13 \mathrm{E}-06$ \\
\hline Adjusted R-squared & 0.476350 & \multicolumn{2}{|c|}{ S.D. dependent var } & 0.016889 \\
\hline S.E. of regression & 0.012221 & \multicolumn{2}{|c|}{ Akaike info criterion } & -5.970495 \\
\hline Sum squared resid & 0.381913 & \multicolumn{2}{|c|}{ Schwarz criterion } & -5.965925 \\
\hline Log likelihood & 7641.249 & \multicolumn{2}{|c|}{ F-statistic } & 2327.940 \\
\hline Durbin-Watson stat & 1.996228 & \multicolumn{2}{|c|}{ Prob (F-statistic) } & 0.000000 \\
\hline
\end{tabular}



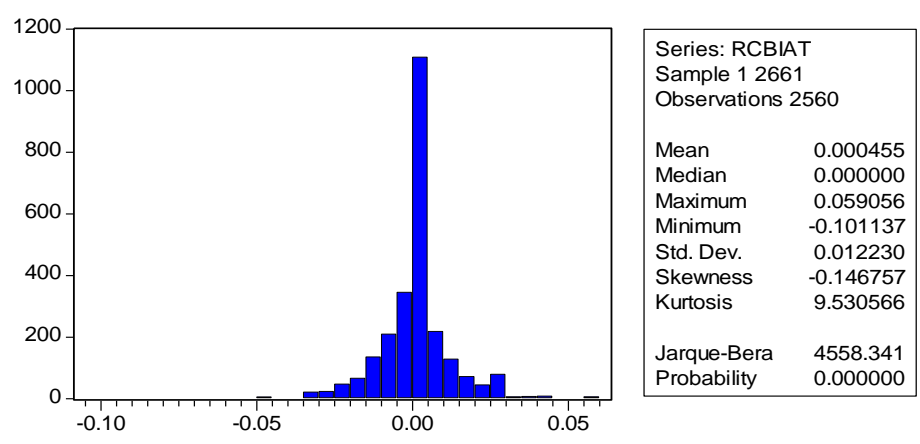

\section{Appendix 6. Correlogram of RC Biat}

Dependent Variable: RCBIAT

Method: ML - ARCH (Marquardt) - Normal distribution

Date: 04/17/14 Time: 12:06

Sample (adjusted): 22561

Included observations: 2560 after adjustments

Convergence achieved after 31 iterations

Presample variance: backcast (parameter $=0.7$ )

$\mathrm{GARCH}=\mathrm{C}(2)+\mathrm{C}(3) * \operatorname{RESID}(-1)^{\wedge} 2+\mathrm{C}(4) * \mathrm{GARCH}(-1)+\mathrm{C}(5) * \mathrm{RVOLBIAT}$

\begin{tabular}{lllll}
\hline Variable & Coefficient & Std. Error & z-Statistic & Prob. \\
\hline $\mathrm{C}$ & $1.12 \mathrm{E}-05$ & 0.000188 & 0.059735 & 0.9524 \\
\hline $\mathrm{C}$ & Variance Equation & & & \\
RESID (-1)^2 & $1.87 \mathrm{E}-05$ & $1.11 \mathrm{E}-06$ & 16.91641 & 0.0000 \\
GARCH (-1) & 0.190928 & 0.013537 & 14.10385 & 0.0000 \\
RVOLBIAT & 0.690026 & 0.016592 & 41.58730 & 0.0000 \\
\hline R-squared & $3.72 \mathrm{E}-06$ & $4.41 \mathrm{E}-07$ & 0.0000 \\
Adjusted R-squared & -0.001317 & Mean dependent var & & 0.000455 \\
S.E. of regression & -0.001317 & S.D. dependent var & & 0.012230 \\
Sum squared resid & 0.012238 & Akaike info criterion & & -6.182754 \\
Log likelihood & 0.383246 & Schwarz criterion & & -6.171332 \\
Durbin-Watson stat & 7918.925 & \multicolumn{2}{|c}{ Hannan-Quinn criter. } & \\
\hline
\end{tabular}

\section{Copyrights}

Copyright for this article is retained by the author(s), with first publication rights granted to the journal.

This is an open-access article distributed under the terms and conditions of the Creative Commons Attribution license (http://creativecommons.org/licenses/by/3.0/). 